\title{
Front Matter: Volume 10885
}

, "Front Matter: Volume 10885," Proc. SPIE 10885, Optical Diagnostics and Sensing XIX: Toward Point-of-Care Diagnostics, 1088501 (22 May 2019); doi: $10.1117 / 12.2523431$

SPIE. Event: SPIE BiOS, 2019, San Francisco, California, United States 


\section{PROGRESS IN BIOMEDICAL OPTICS AND IMAGING}

\section{Optical Diagnostics and Sensing XIX: Toward Point-of-Care Diagnostics}

Gerard L. Coté

Editor

4-5 February 2019

San Francisco, California, United States

Sponsored and Published by

SPIE 
The papers in this volume were part of the technical conference cited on the cover and title page. Papers were selected and subject to review by the editors and conference program committee. Some conference presentations may not be available for publication. Additional papers and presentation recordings may be available online in the SPIE Digital Library at SPIEDigitalLibrary.org.

The papers reflect the work and thoughts of the authors and are published herein as submitted. The publisher is not responsible for the validity of the information or for any outcomes resulting from reliance thereon.

Please use the following format to cite material from these proceedings:

Author(s), "Title of Paper," in Optical Diagnostics and Sensing XIX: Toward Point-of-Care Diagnostics, edited by Gerard L. Coté, Proceedings of SPIE Vol. 10885 (SPIE, Bellingham, WA, 2019) Seven-digit Article CID Number.

ISSN: 1605-7422

ISSN: 2410-9045 (electronic)

ISBN: 9781510624122

ISBN: 9781510624139 (electronic)

Published by

SPIE

P.O. Box 10, Bellingham, Washington 98227-0010 USA

Telephone +1 3606763290 (Pacific Time) · Fax +1 3606471445

SPIE.org

Copyright (C) 2019, Society of Photo-Optical Instrumentation Engineers.

Copying of material in this book for internal or personal use, or for the internal or personal use of specific clients, beyond the fair use provisions granted by the U.S. Copyright Law is authorized by SPIE subject to payment of copying fees. The Transactional Reporting Service base fee for this volume is $\$ 18.00$ per article (or portion thereof), which should be paid directly to the Copyright Clearance Center (CCC), 222 Rosewood Drive, Danvers, MA 01923. Payment may also be made electronically through CCC Online at copyright.com. Other copying for republication, resale, advertising or promotion, or any form of systematic or multiple reproduction of any material in this book is prohibited except with permission in writing from the publisher. The CCC fee code is 1605$7422 / 19 / \$ 18.00$.

Printed in the United States of America by Curran Associates, Inc., under license from SPIE.

Publication of record for individual papers is online in the SPIE Digital Library.

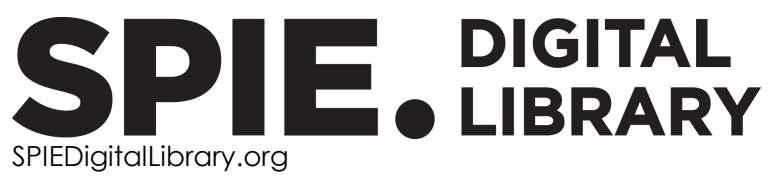

Paper Numbering: Proceedings of SPIE follow an e-First publication model. A unique citation identifier (CID) number is assigned to each article at the time of publication. Utilization of CIDs allows articles to be fully citable as soon as they are published online, and connects the same identifier to all online and print versions of the publication. SPIE uses a seven-digit CID article numbering system structured as follows:

- The first five digits correspond to the SPIE volume number.

- The last two digits indicate publication order within the volume using a Base 36 numbering system employing both numerals and letters. These two-number sets start with $00,01,02,03,04$, 05, 06, 07, 08, 09, 0A, OB ... 0Z, followed by 10-1Z, 20-2Z, etc. The CID Number appears on each page of the manuscript. 


\title{
Contents
}

\author{
$\checkmark \quad$ Authors \\ vii Conference Committee
}

SESSION 1 OPTICAL IMAGING APPROACHES

1088503 Direct reconstruction of qualitative depth information from turbid media by a single hyper spectral image [10885-3]

SESSION 2 PPG IMAGING APPROACHES

$1088507 \quad$ RGB camera-based noncontact imaging of plethysmogram and spontaneous low-frequency oscillation in skin perfusion before and during psychological stress [10885-7]

1088508 Imaging photoplethysmography for assessment of chronic pain patients [10885-8]

\section{SESSION 3 OPTICAL IMAGING OF BLOOD}

$10885 \mathrm{OA}$ Statistical study of blood cell populations by very wide-field bimodal phase/fluorescence imaging [10885-10]

10885 OC Label-free identification of neutropenia using deep-ultraviolet microscopy [10885-12]

SESSION 4 OPTICAL ABSORPTION TECHNIQUES FOR HUMAN AND VETERINARY APPLICATIONS

10885 ol Biophotonics in veterinary medicine: the first steps toward clinical translation [10885-20]

SESSION 5 ON-CHIP AND PAPER OPTICAL BIOMARKER DETECTION

10885 OL Miniaturization of fluorescence detection for PCR chip [10885-23] 
SESSION 6 RAMAN SPECTROSCOPY AND SURFACE ENHANCED RAMAN FOR BIOMEDICAL APPLICATIONS

10885 ON Investigation and calibration of non-essential amino acids using a custom built Raman spectroscopy system [10885-25]

$1088500 \quad$ Raman spectral analyses of amino acids in life processes [10885-26]

SESSION 7 OPTICAL GLUCOSE MONITORING APPROACHES

10885 OR On feasibility of near-infrared spectroscopy for noninvasive blood glucose measurements [10885-29]

10885 OS An optimized non-invasive glucose sensing based on scattering and absorption separating using near-infrared spectroscopy [10885-30]

10885 OT Hybrid GaSb/Si swept-wavelength laser sensor technology for next generation wearable healthcare device platform [10885-31]

10885 OU Ultrasonic-assisted point one-shot mid-infrared Fourier spectroscopy for realization of ear-cliptype non-invasive blood glucose sensors: ultra-miniature point one-shot mid-infrared spectroscopic imager (diameter: $10 \mathrm{~mm}$; thickness: $25 \mathrm{~mm}$ ) configured using a single lens (1st report) [10885-32]

10885 OV Ultrasonic-assisted point-one-shot mid-infrared Fourier spectroscopy for realization of ear-clip type non-invasive blood glucose sensors: ultrasonic-assisted method for production of a reflection plane near the skin surface and detection of the blood glucose absorption peak in mice (2nd report) [10885-33]

\section{POSTER SESSION}

10885 0X Temperature near-infrared absorption spectrum monitoring for in vivo tissue based on a new scattering-independent measurement [10885-35]

10885 OY Assessment of wavelengths with skin tones for an implantable FRET-based glucose biosensor [10885-36]

$10885 \mathrm{OZ} \quad$ Flexible electronic bands for the dynamic optical spectroscopic assessment of systemic lupus erythematosus in finger joints [10885-37]

1088514 Cancer discrimination based on real-time AMD (Analog Mean-Delay)-FLIM (Fluorescence Lifetime Imaging Microscopy) [10885-1] 


\section{Authors}

Numbers in the index correspond to the last two digits of the seven-digit citation identifier (CID) article numbering system used in Proceedings of SPIE. The first five digits reflect the volume number. Base 36 numbering is employed for the last two digits and indicates the order of articles within the volume. Numbers start with 00, 01, 02, 03, 04, 05, 06, 07, 08, 09, OA, OB...0Z, followed by 10-1Z, 20-2Z, etc.

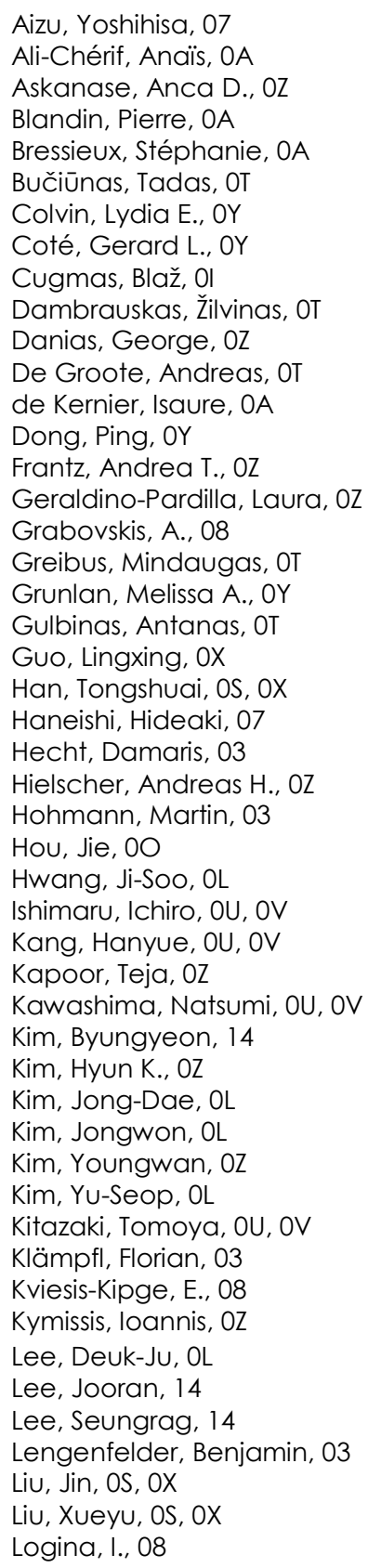

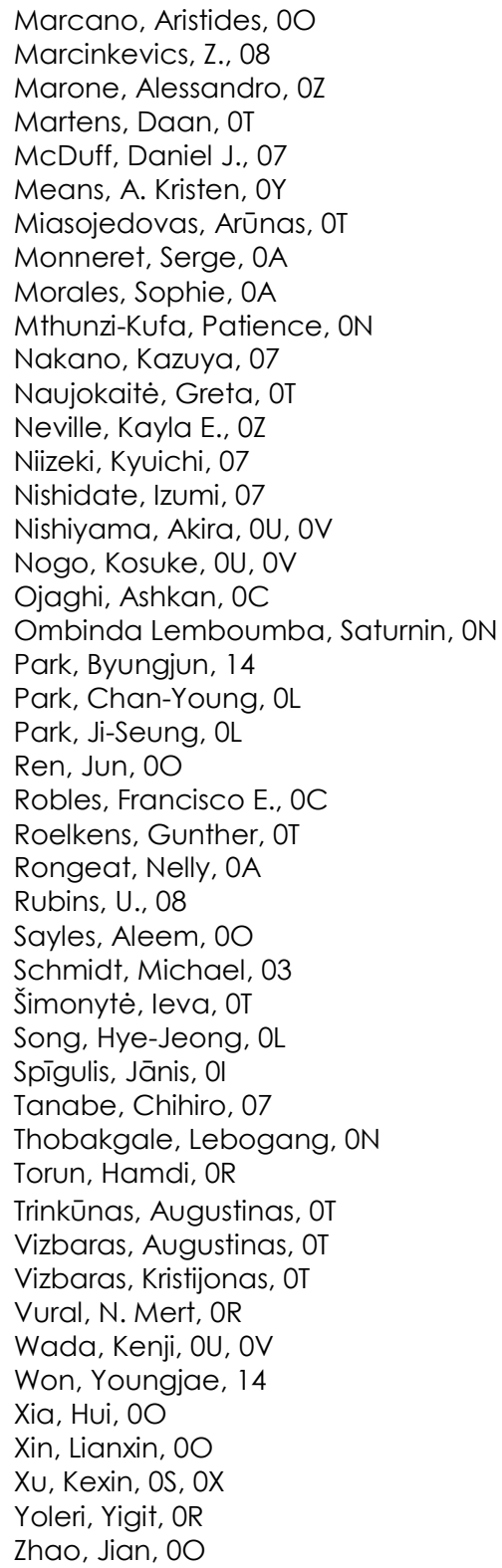


Proc. of SPIE Vol. 10885 1088501-6

Downloaded From: https://www.spiedigitallibrary.org/conference-proceedings-of-spie on 25 Apr 2023 Terms of Use: https://www.spiedigitallibrary.org/terms-of-use 


\section{Conference Committee}

Symposium Chairs

James G. Fujimoto, Massachusetts Institute of Technology (United States)

R. Rox Anderson, Wellman Center for Photomedicine, Massachusetts General Hospital (United States) and Harvard Medical School (United States)

Symposium Co-chairs:

Jennifer K. Barton, The University of Arizona (United States)

Wolfgang Drexler, Medical University of Vienna (Austria)

Program Track Chairs

Ammasi Periasamy, University of Virginia (United States)

Daniel L. Farkas, University of Southern California (United States) and SMI (United States)

Conference Chair

Gerard L. Coté, Texas A\&M University (United States)

Conference Program Committee

Zane A. Arp, U.S. Food and Drug Administration (United States)

Brent D. Cameron, The University of Toledo (United States)

Blaž Cugmas, University of Latvia (Latvia)

H. Michael Heise, University of Applied Sciences of South-Westphalia, Iserlohn (Germany)

Kristen C. Maitland, Texas A\&M University (United States)

Michael J. McShane, Texas A\&M University (United States)

Kenith E. Meissner, Swansea University (United Kingdom)

Timothy J. Muldoon, University of Arkansas (United States)

Aydogan Ozcan, University of California, Los Angeles (United States)

Babak Shadgan, The University of British Columbia (Canada) 


\section{Session Chairs}

1 Optical Imaging Approaches

Madeleine S. Durkee, University of Chicago (United States)

2 PPG Imaging Approaches

Babak Shadgan, The University of British Columbia (Canada)

3 Optical Imaging of Blood

Timothy J. Muldoon, University of Arkansas (United States)

4 Optical Absorption Techniques for Human and Veterinary Applications

Blaž Cugmas, University of Latvia (Latvia)

5 On-chip and Paper Optical Biomarker Detection

H. Michael Heise, University of Applied Sciences of South-Westphalia, Iserlohn (Germany)

6 Raman Spectroscopy and Surface Enhanced Raman for Biomedical Applications

Zane A. Arp, U.S. Food and Drug Administration (United States)

7 Optical Glucose Monitoring Approaches

Brent D. Cameron, The University of Toledo (United States) 